Zárate-Rueda, R., Murallas Sánchez, D. y Ortega-Zambrano, C. (2021). Inclusive education and labour insertion from a capabilities approach: a phenomenological and functional diversity perspective. Revista de Investigación Educativa, 39(1), 265-282.

DOI: http://dx.doi.org/10.6018/rie.427881

\title{
Inclusive education and labour market insertion from a capabilities approach: a phenomenological and functional diversity perspective
}

\author{
Inclusión educativa e inserción laboral desde el enfoque de \\ capacidades: una perspectiva fenomenológica y de diversidad \\ funcional
}

\author{
Ruth Zárate-Rueda*, Daniella Murallas-Sánchez** and Catalina Ortega-Zambrano** \\ *School of Social Work. Universidad Industrial de Santander (Colombia) \\ **Center for Technology and Innovation Management Research, INNOTEC. Universidad Industrial de Santander
}

(Colombia)

\begin{abstract}
This study focuses on the analysis of life experiences in the academic and work environment of professionals with functional diversity graduated from the Universidad Industrial de Santander-UIS. Our research has been conducted under the interpretative paradigm and uses a phenomenological approach in order to evaluate the participants' lived and felt experiences during and after their time at university. Our results have been validated through the use of triangulation, contrasting the information gathered from theory, reality and researchers. The results indicate that architectural and psychosocial barriers are an obstacle to the differential needs of students from the perspective of inclusive education; besides, it has been found that the labour market does not offer inclusive opportunities, and participation is limited. This has led us to conclude that there are gaps in access to education and work regarding equal opportunities and the respect for differences. Finally, we note that the implementation of Inclusive Education Policies at university is essential for the integration of this demographic, specifically in processes that combine the Capabilities and Human Rights approaches.
\end{abstract}

Correspondencia: Ruth Zárate Rueda, ruthzaraterueda@gmail.com, ruzarate@uis.edu.co, Universidad Industrial de Santander, Carrera 27 Calle 9, Bucaramanga, Santander. Escuela de Trabajo Social 
Keywords: inclusive education; labour market; capability; phenomenology; diversity; educational policy.

\section{Resumen}

El estudio se enfoca en el análisis de experiencias de vida en los ámbitos académico y laboral de egresados con diversidad funcional de la Universidad Industrial de Santander-UIS. La investigación se desarrolla desde el paradigma interpretativo y el enfoque fenomenológico para dimensionar las experiencias vividas y sentidas durante y después de su paso por la universidad; asimismo, los resultados se validan mediante la triangulación por contraste de información entre teoría, realidad e investigador. Los resultados señalan que las barreras arquitectónicas y psicosociales son un impedimento para atender las necesidades diferenciales de los estudiantes desde la inclusión educativa; además, se encontró que el mercado laboral no ofrece oportunidades incluyentes y la participación es limitada; con lo cual se concluye que existen brechas en el acceso a educación y trabajo, igualdad de oportunidades y respeto por las diferencias. Finalmente, se denota que la implementación de la Política de Educación Inclusiva universitaria es imperante para vincular a este segmento de población, específicamente con procesos que integren el enfoque de capacidades y el Enfoque de Derechos Humanos.

Palabras clave: educación inclusiva; mercado laboral; capacidad; fenomenología; diversidad; política educativa.

\section{Introduction}

Education involves a connection between intellectual training, capabilities and social skills, developed while interacting in the social medium; in consequence, it is an essential complement for human beings, as it provides them with the necessary objectivity to understand daily life aspects and situations. For people with functional diversity, education is a tool for empowerment, since academic training allows for a change in perception regarding the differential capabilities that in turn help to boost other abilities.

In this regard, inclusive education, as a fundamental right, involves not segregating anybody in education on the bases of their functional diversity, and recognizes their participation under equal opportunities (del Pozo-Armentia et al., 2020). Likewise, higher education is considered to be more efficient as it is more inclusive. In other words, the heterogeneous nature of the students' group adds value to the learning process of the whole university community, not only for students with functional diversity (Villalobos et al., 2015; Gross, 2016). In consequence, the incorporation of inclusive educational settings involves respecting differences and also obtaining authentic results during the teaching process (Kilinc, 2019).

Inclusive education is inherent to labour insertion of the functionally diverse population, since access to higher education is equivalent to sustaining and continuing one's life project in the work area (Bliksvær, 2018; Büscher-Touwen et al., 2018). However, together with the gaps represented by reduced access to university, there is limited participation in the labour market (Artiles, 2019), as needs are not fully comprehended, and the policies, practices and processes implemented in companies for insertion are 
usually governed by basic standards, with deficiencies in accessibility; therefore, it is necessary to introduce inclusive practices in hiring processes, including functional diversity components (Williams \& Hagood, 2019), related with permanence, and alternatives for career plans that guarantee extended labour experiences (Aoki et al., 2018).

The employability of the functionally diverse population results from the modification of negative perceptions, highlighting emerging capabilities, and the combination of opportunities to participate in different contexts (Jurado \& Soler, 2016). In spite of the ideal setting for work performance, these individuals face obstacles related with prevailing prejudice, discrimination and stereotypes (Vornholt et al., 2018). Companies have limited and inadequate training on their differential conditions (Soares, 2019) and "employment has become such a dominant ethic of government disability services but it does little to value the diversity of people with disabilities" (Darcy et al., 2016, p.1243).

Therefore, the guiding question is: Which are the inclusive education and work insertion processes experienced by functionally diverse UIS alumni, both as students and professionals, based on their perceptions experienced and felt in their daily lives?

\section{Capabilities Approach}

A capabilities approach stems from the interest in assessing the quality of life and well-being of individuals, including social, economic and political aspects. This is stated from the standpoint of the development of abilities by human beings and the influence these abilities have in the attainment of freedom, well-being, opportunities, equality and the optimal fulfilment of their rights. For the present study, the postulates and perspectives of Martha Nussbaum and Amartya Sen on this approach were considered. First, Nussbaum, from the perspective of human dignity; second, Sen's and his take on freedom as capability.

The capabilities approach is conceived by Nussbaum (2007) as an alternative to economic-utilitarian approaches that dominated and still dominate the debates on the quality of life, in which the goal of development is perceived in purely economic terms. In consequence, through this approach, social, economic, political and cultural unbalances remaining in society have been analysed; likewise, it is related with the way in which all human beings have the same possibilities to perform their capabilities (Vorhaus, 2015). Under this premise, Rawls (1995), states that each person possesses an inviolability founded on justice that even the welfare of society as a whole cannot override. For this reason, justice denies that the loss of freedom for some is made right by a greater good shared by others. This justice implies that the freedom of equality of citizens is an established right.

According to the above, the fundamental premise of the capabilities approach is human dignity, whereby human beings live according to this dignity, which in turn involves an authentically human functioning; therefore, it holds a direct connection with the Human Rights Approach and its orientation towards the result, when analysing whether it is compatible with a life in agreement with human dignity (Nussbaum, 2007, 2016).

Lastly, Nussbaum considers that all human beings have a minimum threshold to develop their capabilities, and if these are under this threshold, a lack of basic justice can be identified; for this reason, the author states that each one of these capabilities 
should be strengthened by providing opportunities in the form of proper assistance and education, as these become a set of unnegotiable social rights, perceiving the importance the development of core capabilities has for individuals and the justification of the necessary expenses of a country to invest in a better quality of life for functionally diverse people (Nussbaum, 2007).

The second perspective is Amartya Sen's, who makes a distinction between the attainment of objectives and freedom. The former is understood as what human beings strive to attain; the latter refers to the real opportunity they have to attain what they value; consequently, the capabilities approach shows the need to examine the freedom to fulfil and to fulfil oneself in general, and the capacity to function in particular (Sen, 1999).

If a person decides to live in a particular way, he/she should think whether they possess the freedom to do it; that is, the corresponding capabilities to attain their goals and the different alternatives they have to choose from (Sen, 2000, 2012). In this way, it is concluded that every individual should possess the freedom to choose whether they want to do or to be this or that, taking decisions to function in the way they consider most adequate.

The capabilities approach is usually focused on the analysis of inequality (Urquijo, 2008), based on social justice as a reference point to attain equality in all spheres of human development. Based on this, there exist different conceptions as starting points to define this equality, and hence, theoretical fundamentals which reaffirm once again the need all human beings have to have the same opportunities to achieve whatever they have defined as their life's project. In consequence, it is worth considering "Which would be a fair treatment for functionally diverse people? A fair society would not stigmatize these people, nor would it block their development; it would rather promote their health, education, full participation in social and even in political life" (Nussbaum, 2007, p.111).

\section{Functional Diversity}

The concept of functional diversity originated in the dynamic perceptions on disability; in consequence, three models have been proposed to explain it: the medical, social and bio-psychosocial models. From the medical model it was made evident that the causes to justify disability are scientific, since there is a special condition in terms of health, and hence rehabilitation is required (Palacios, 2008). From the social model standpoint, disability is no longer perceived as a disease distinctly associated to health; under this perspective, this model intends to vindicate this group of people as full subjects of rights and to understand that society imposes barriers and disabling discrimination onto them (Santórsola et al., 2013). The ICF (International Classification of Functioning, Disability and Health) proposes the bio-psychosocial model, resulting from the integration and balance between the medical and social models, thus providing a coherent view on disability from the biological, individual and social perspectives (World Health Organization [WHO], 2001).

In the 1960s an alternative and critical discourse regarding the conceptions on disability emerged, and it started with the so called "Philosophy of Independent Living"; in this way, under the perspective of the Independent Living collective 
(Spain), the concept of dis-ability is anchored in the denial of the ability, linked to the medical and social discourse built in daily practice (Rodríguez \& Ferreira, 2010). In consequence, the movement proposes the construction of a new discourse, the one of functional diversity, based on the fact that "people do not have a deficiency, but rather diversity, from which it can be inferred that they are not suffering from disability, but from marginalization and injustice due to their diversity" (Canimas, 2015, p.82); in turn, it points to the richness of diversity, to vindicate functional differences, not to ignore the use of language that imposes labels (handicapped, deficient) and the impact it has on the construction of one's identity (Velázquez et al., 2013; Mañas \& Iniesta, 2016).

\section{Method}

The method was based on an interpretative paradigm, which aims to interpret reality, the meaning that people give to facts, their perceptions and intentions (Sandín, 2003; Cardona, 2013). For the study mentioned, the impressions, sensations and experiences of functionally diverse alumni at the time they entered university and the work market were considered. In connection with this epistemological foundations, a qualitative methodology was implemented, as the study deals with the experiences, behaviours, feelings, movement and interaction of human beings with the social and cultural world, building up findings with non-statistical techniques which aim to understand a phenomenon from within, in a natural context, from the perspective of its participants (León \& Montero, 2015; Naupas et al., 2018).

Within this context, the study was conducted from a phenomenological approach, whose aim is to "study phenomena as they are perceived by human beings by means of the intuition and knowledge acquired from the phenomenon" (Pimienta et al., 2018, p.38). According to Husserl, phenomenology makes it possible to clarify all those aspects that make an experience possible from an objective standpoint, paying attention to temporary events and the identity of the subjects (Chavez \& Yáñez-Canal, 2018); in this respect, three attributes are established: human beings are immersed in a space and time; the limitation of existential experience to the settings and times experienced; and the materialization of certainties (the undoubtable) in the space-time insertion (Baeza, 2015, p.61). Hence, the accounts from alumni made up the way in which they felt and appreciated the different experiences they faced on a daily basis as functionally diverse people, within the educational and work contexts which, besides being selective, excludes them in social terms.

From the standpoint of phenomenology, four basic existential facts are proposed: the experienced setting (spatiality), the body experienced (corporeality), the time experienced (temporality) and the human relationships experienced (relationality or communal being) (Van Mannen, 1990, in Sandoval, 2002). For the analysis process, the human relationships experienced were considered, based on the academic and work experiences of functionally diverse alumni with their work peers, colleagues, members of the university campus, the faculty, the administrative staff and the community in general. 


\section{Objectives}

To answer this problem question, the following objective was formulated: to analyse the inclusive education and work insertion processes experienced by functionally diverse UIS alumni, both as students and professionals, based on their perceptions experienced and felt in their daily lives.

\section{Population and Sample}

The population sample was made up of UIS alumni from different academic programmes offered at the institution; likewise, an inclusion criterion considered was the fact of having pursued undergraduate studies on the central campus. Homogeneous sampling was used to select the population sample, since the people selected share the same profile or characteristics (Hernández-Sampieri \& Mendoza, 2018), as they have studied in and graduated from the same university; they share a condition of functional diversity; they have experienced similar situations in academic and work settings, and they share similar episodes, processes and situations that consolidate their resilience capacities. The chain sampling (snowball) technique was also used in "groups which are difficult to access. It is based on finding an individual in that population who may refer others, who in turn may successively refer others, till the sample size determined in the methodological design is reached" (Hernández \& Carpio, 2019, p.78); in this sense, the sample was confirmed by identifying and incorporating professional UIS participants, who in turn referred another person with the same characteristics as the ones considered in this study (Hernández-Sampieri \& Mendoza, 2018).

Although the population group share similar characteristics, their profile has some differentiating features, since 3 of the seven participants were female and 4 male, from different socio-economic stratification levels, varying between 3, 4 and 5. Besides, this group is made up of people who pursued professional majors at the Schools of Human Sciences, Physics-Mechanics and Physics-Chemistry. Regarding their diverse condition, these include quadriparesis resulting from an accident, congenital blindness, hemiparesis, and hemiplegia.

\section{Instrument}

The collection of information was made through semi-structured interviews, since the researcher has a general plan for the discussion topic, a situation that motivates the interviewee to "speak with his/her own words" and provide detailed descriptions in the first person (experience, conscience) (Packer, 2018, p.64). The interviews with alumni were guided by eight question related with their life experiences, both lived and felt, from the category inclusive education, getting more precise information on aspects like: access to the institution premises, signalling for visually impaired people, support processes by the Academic Excellence program, pedagogical material corresponding to every functionally diverse condition, strategies for the evaluation of content in different subjects, support from the administrative and student bodies, and interaction with their classmates. 
In the labour insertion category, subcategories like the following were included: ways to access employment offers, access to employment, connection of the job with the profession and trial periods prior to hiring. Likewise, they were told about the informed consent in order to get their voluntary participation and truthful information on the study (Kvale, 2011). All participants expressed their approval to make some of their comments and perspectives public.

Although the validity criterion is the subject of debate in qualitative research, in order to avoid bias and wrong interpretations (Maxwell, 2019), the instrument was validated through the review-by-experts technique (Robles et al., 2016), which consisted in choosing three professionals under the criterion of their expertise and specialization in educational needs and inclusion. They received the predetermined form, as they have experience in the area of functional diversity, and besides, one of them presents with left hemiparesis. Finally, the interview format was restructured by suggestion, which led to two questions being omitted and the addition of terms according to the subject of research, besides aspects related with writing. To determine the reliability of the interview, a corroboration check was made by the participants (Vasilachis de Gialdino, 2019), when one of the subjects of research was asked to proofread the document in terms of content and form, and some semantic and conceptual recommendations for modifications were followed.

Participant observation was used in every interview. This type of observation makes it possible to study in situ (from the inside), involving the researcher and the informants in social interaction and allowing researchers to know directly all the information the subjects of study hold in their own reality (Peña, 2011; Cais et al., 2014). This technique was used, understanding that the information is not only collected by means of questions to participants, but it is also necessary to observe their attitudes, posture, verbal and non-verbal language.

\section{Data Collection and Analysis Procedure}

For this study, the process started with the selection and categorization of the information collected in the interviews conducted. Categories like the experiences lived and felt by participants emerged, besides analysis categories such as academic experience, which in turn include subcategories like architectural barriers, teacher/student support and peer support; then we find work experience, with the subcategories of time, positions occupied and work connections. Two additional categories emerged here, the former called educational inclusion, with the subcategories of awareness raising, enhancing capabilities and inclusive infrastructure; the latter called labour insertion, including the subcategory jobs board or jobs centre.

It is worth mentioning that the construction of categories was based on prior experience related with the subject of study, through the immersion of the research team in the field, and it was guided by the "theories and concepts we have worked in the theoretical framework and the state of the art, as well as by guides and instruments" (semi-structured interview and participant observation) (Ballestín \& Fàbregues, 2018, p.188).

To validate the analysis of results, a triangulation process was followed. It consists in an interpretation that assesses the consistency of the findings from different angles, 
contrasting the information coming from different sources in order to identify differences pointing to alternative dimensions that have not been contemplated before or which have been previously approached (Bonilla-Castro \& Rodríguez, 2013; Niño, 2019). These components are related with the interaction of three informants: the authors cited in the theoretical-conceptual aspects, the expressions of the participants through their testimonies, and the researcher or research team responsible for the study. These elements are mentioned below:

The theory, which makes it possible to study the capabilities approach and functional diversity in more depth, from the educational and work perspective, and to find in the conceptualizations the categories for analysis that are approached in the theoretical-conceptual referent, and the state of the art. The reality, expressed by participants who are UIS alumni from their subjectivity, through expressions that include their perceptions, experiences and reflections regarding the academic and work settings. The researcher category, which involves the study group members, who are subjects belonging to a historical moment, with knowledge, feeling and appreciations as part of their connotations. The relationship among these three components is articulated in a triangular form, with relationship points that combine into a construct called interpretative triangle, which is based on the three-part combination of epistemological assumptions (theory), findings (reality) and inter-subjectivity (researcher-reality). Finally, it is inferred that triangulation consists in the multiplicity of perspectives that emerge from a threefold dialogical relation: theory, reality and researcher (De Tezanos, 1998).

\section{Findings}

To guarantee the confidentiality of this phase in the process, each one of the participants was identified by means of a code including letter " $\mathrm{E}$ ", from the word egresado, meaning alumnus in Spanish, followed by number 1 to 7; which resulted in E1, E2, E3, E4, E5, E6 to E7.

The description of the findings is divided into two axes, which are in turn divided into categories and subcategories.

\section{Axis I: Experiences endured and felt}

This axis comprises academic and work experiences of participants as students and currently as alumni.

\section{Academic experiences: "an opportunity to know about the abilities each one of us had" (EI)}

This category shows the academic experiences of alumni when they were studying at the university, in aspects related with the way in which subject contents were assessed, access to campus and the development of skills were made possible. To describe each one of these aspects, this category comprises the following sub-categories: architectural barriers, teacher/student support and peer support. 
Some universities make efforts to respond to the needs of functionally diverse students (Cortés \& Moriña-Díez, 2014), while others remain unchanged before the constant dissatisfaction of those students who cannot move safely around campus (Oviedo-Cáceres \& Hernández-Quirama, 2020); undoubtedly, architectural barriers hinder mobility from the start of university life, added to other types of obstacles that continue to be found (negative attitudes, lack of adjustment to curricula, inaccessible methodologies) (Moriña \& Morgado, 2018) and denote the challenges of universities to promote the skills of their students with differential needs (Moriña \& Perera, 2020), starting from adjustment to the classroom to the participation in extracurricular activities (Kunnath \& Mathew, 2019).

Participant E2 indicated that "I could only enter the university through the ground floor. At the entrance the watchman opened the gate and I had access to different laboratories there"; participant E7 stated that he fell several times on the university campus and participant E6 often had to get to the building in the farthest end of the university, a situation that forced him to walk long distances and face physical difficulties.

Teacher/student support was vital for alumni. To some, the process was positive, since they were allowed to enhance their capabilities. For Brownell et al. (2020) a starting point must be teacher education, as there are shortcomings in the lack of measures shared regarding capacities, knowledge and disposition by teachers to promote assertive pedagogical practice in different contexts; likewise, Pugach et al. (2020) highlight the approach to curricula for the education of teachers with functionally diverse students, starting from inclusive practices that lead them to ask themselves, "how should we help students who are struggling to reach the goal?" (p.99). Ultimately, working with these students enables teachers to develop honest relationships and enrich their knowledge on teaching methods (Akbieva et al. 2015).

For participants E5 \& E2, the support of their schools' administrative units was decisive to conduct their professional studies and be included in other academic settings; however, some hindrances/inconveniences must be recognized, like the ones faced by participants like E2, who encountered teachers who "refused to move their courses to a floor with better access", a situation that hindered their access to classrooms due to the lack of ramps and lifts, which resulted in the participant's classmates having to lift him and carry him to the corresponding classroom. Moriña et al. (2013) argue that due to their special needs, students with functional diversity have more contact and interaction with the teachers than the rest of their classmates; hence, when the teacher's attitude is positive, this factor turns into help and it acquires more value in the learning process. In consequence, the university professor who teaches people with functional diversity, should tend to the academic needs of students, related with supplying adapted materials, facilitate their integration to the class dynamics and mediate in the resolution of problems the student may face (Álvarez-Pérez \& López-Aguilar, 2015).

"We met with several classmates to promote the construction of the elevator. We proposed the idea to the dean and raised some money" (E5). Counting on the support of peers is also a fundamental aspect to achieve an optimal academic training process; hence, it is necessary to prevent negative attitudes in the form of prejudice and discrimination (Girli et al., 2016). According to Polo et al. (2020), students who keep a sporadic contact with functionally diverse peers have a positive attitude, depending on the level of disa- 
bility and the continuity of the relationship; therefore, these authors highlight the role of the university to promote training programs that promote understanding functional diversity by students, faculty, administrative staff and the community (Polo et al., 2018).

\section{The work experience: "an opportunity to work in what we studied, and to show how good we are" (E5)}

The category of work experience is related with the approach some alumni have had to functional diversity in the work setting; it includes subcategories like the time at work, the positions undertaken and the work connections that have facilitated access to the labour market.

Regarding the time worked, participant E1 has never been employed after graduating as a professional; however, the case of E4 is different, as he has been working for approximately seven years since he acquired his differential condition, besides being working in his profession. In turn, participant E7 states that he has worked uninterruptedly, "I haven't stopped working since I graduated" and participant E5 was working for four years nonstop at a non-governmental organization- NGO. To some participants, keeping a job for several years has not been easy, due to the uncertainty resulting from changes in the functions they must perform, trial periods, the types of contracts under which they are hired, changes in staff, the discrimination factors they face on a daily basis and the work risks they are exposed to.

With regards to the jobs performed by the interviewee, in some cases they differ from the major they have studied. Participant E5 has worked as a teacher, but as a Master's alumnus she has not had a job that has allowed her to apply her knowledge in the different areas of performance of her profession; on the other hand, participant E3 provides assistance to an orchestra made up by music students at the university; this activity is not directly related with his studies, but he has some business projects in line with his degree. Some alumni have reached better work opportunities due to graduate studies. Participant E4 stated "they met me and they saw what my specialization was going to be, and so they continued to hire me". He deepened his knowledge in his area of performance through Master's studies, a fact that also served to increase his income.

For each one of the alumni, the experience of starting a job has been differential; some of them have had more opportunities than others, depending on a variety of family, academic or work connections they have been making. Participant E2 contacted a school that has included functionally diverse teachers; on the other hand, alumnus E6 created her own artistic corporation, and alumnus E7 started a non- profit foundation. This type of scenarios become one way of developing capabilities which, somehow, the work environment has not created.

\section{Axis 2: Educational inclusion of students, a viable alternative for the labour inser- tion of alumni}

This axis presents the contributions of participants from their experiences in the academic and work spheres in order to contribute to the construction of equality. They 
are classified into the categories of inclusive education and labour insertion; the former refers to proposals on the undergraduate process and the latter to alumni.

Regarding the contributions of alumni towards inclusive education and labour insertion, we can highlight their existing agreement with the Inclusive Education Policy approved by the University in July 2019. This is due to the connection existing between the agreements made by the institution on the university community and the ideas expressed by the participants.

\section{"To be at the university, a study on what people with differential disabilities require should be made" (E3): an option for inclusive education}

It is necessary to have clarity on the importance of generating sensitization processes in the university community, including students, teachers, administrative and operative staff. In no way is it productive to "separate" diversely functional students from the rest of the population in the institution; that is why, for participant E3, before creating programs, it is a must to start form the basis of the process, namely, sensitization. It is worth asking ourselves Whose job is it to work to eliminate traditionalistic concepts and negative actions affecting people's dignity? All human beings have rights, and so there is a collective obligation to provide everybody in the world with whatever they need, and all individuals have the collective duty to find ways of living and cooperating jointly so that all human beings can live decent lives (Nussbaum, 2007).

Alumni have proposed the need to enhance the capabilities of students in the undergraduate process in order to prepare them to compete in the labour market with the rest of the population. Alumnus E7 highlights the importance of perceiving oneself as capable to do whatever one has aimed for as a professional, since possessing differential conditions should not be an excuse not to do it.

Under Sen's perspective, capability may not be directly observed, since the data required to measure a set of capabilities are extensive; however, it is more viable to identify functioning or achievements attained (Urquijo, 2008). "If the operations ${ }^{1}$ attained make up a person's well-being, so the capability to attain functioning shall make up that person's freedom and his/her real opportunities to attain well-being" (Sen, 1999, p.54). The well-being of functionally diverse students is promoted when they can develop in the setting they are and they may enjoy real freedom. Consequently, if the alternative to act freely and choose different ways of living and being is promoted, they will have a better quality of life and their well-being will be favoured (Sen, 1999; Colmenarejo, 2016; Toboso, 2018).

As shown in Axis 1, in the category of academic experiences of alumni, for participants E2 and E4, the architectural barriers they found in their way prevented inclusive access to the different areas of the university. Consequently, they propose an inclusive infrastructure. For Nussbaum (2007), some time ago, it was impossible to consider that a person with auditory difficulties or who was on a wheelchair might get access to higher education or participate in public life; in this way, it seemed possible to avoid the high costs of redesigning and adapting public spaces for the functionally diverse.

1 The states and actions which reflect what a person may do or be (Sen, 1985, in Urquijo, 2008). 
Likewise, regarding students, the alumni E1, E5 and E6 suggest the importance of promoting their association to the different affiliation groups offered by the university; organizing leisure and educational activities in which the whole university community takes part, as a sensitization strategy regarding functional diversity; implementing pedagogical tools and learning techniques; keeping communication with the teachers who have students in their groups who might require specific support regarding mobility, assessment and learning.

\section{"A jobs board as a springboard to labour insertion" (E7): a vision of alumni}

In this subcategory alumni E3, E6 and E7 proposed an alternative solution to facilitate labour insertion by functionally diverse professional alumni from UIS (Jobs board as a "springboard"). In this regard, the alumni have two different positions. For alumnus E6, the jobs board should make a distinction between functionally diverse people and the rest of the population; to her, this will make it possible for the university to certify that during the five years of undergraduate courses the person was functional. On the other hand, alumnus E7 considers that the person should not be hired on account of his/her disability; on the contrary, he proposes that this is perceived as one characteristic among all the features of that human being, and that the position to be occupied is "normalized", meaning the elimination of the distinction between disability/ not disability.

Regarding the above, participants E2 and E7 estimates that, consistent with the empowerment of capabilities for students, it is essential that functionally diverse people face trial periods, like the rest of the population who wish to attain a position in the labour market. Likewise, alumnus E7 considers that the strategy of the jobs board should keep a margin in their procedures, in order to prevent dependence of alumni on the institution, and he reflects that the participation of the university should stop at some point. The need to have differential treatment with the functionally diverse population has been affirmed, but also, there must be some kind of balance between equality (including the rights, recognition of functional diversity and opportunities) and dependence (E5). That is why, from the conceptual perspective, Nussbaum (2007) highlights that the assistance provided to this group of people allows them to acquire capabilities (choice, reasoning, affiliation, etc.); in consequence, it is necessary to identify that they wish to be respected as equal citizens, with the right to adopt different options and life styles, comparable to the ones the rest of the population has. If functionally diverse alumni have decided to be professionals and exert on what they have learned in order to contribute to society, this society should award them freedom "as the individual capacity to do things you value" (Sen 1999, in Urquijo, 2008), and "the real opportunity to attain what is valued" (Sen, 1999, p.45).

In addition, participants E1 and E4 consider it necessary to promote communication with the university in order to promote labour insertion, with binding calls for the different projects in which the institution takes part. Likewise, (it would be important to) create the opportunity to integrate them from the academic units; for example, through teaching; promoting interest to hire functionally diverse professionals and motivate alumni who are businessmen to create job opportunities for this group of people. 


\section{Discussion and Conclusions}

Stereotypes and prejudice limit access to settings with opportunities, equality and the fulfillment of rights for functionally diverse people, as social reactions that interpret their bodies as "disabiling" and the exclusion discourse reflect the way in which this population builds their identity (Pașcalău-Vrabete \& Băban, 2018). This set of actions frames them in a world of disadvantages, where the way in which things are organized in society does not leave room for the functionally diverse, and social practices are not coherent with their life experiences either (Williams et al., 2018).

Hence, in the implementation of inclusive processes, shortcomings are made evident when the capabilities approach is undertaken, since functionally diverse people continue to be stigmatized through educational gaps related with architectural barriers that prevent fitting into the different physical areas, and these must be adapted to universal standards (Melero et al., 2018); likewise, psychosocial barriers related with the attitudes of faculty, characterized by the lack of empathy and interest in their priorities (LopezGavira et al., 2019), must be replaced by comprehensible methodological strategies and practices that involve emotions and motivation, as teachers' actions are determining in the success or failure of the inclusive education process (Aguilar et al., 2019; Moriña, 2019). The aforementioned is complemented by the classmates' attitudes (González \& Roses, 2016) and the consolidation of the role of Higher Education in inclusion (Denisova et al., 2016) by identifying the obstacles and challenges that universities have to achieve it (Paz-Maldonado, 2020).

In parallel, the labour market does not offer opportunities that fit the differential needs of alumni (diverse condition, gender, socioeconomic background) (Li et al., 2017; Jiménez \& Ruiz, 2018; Bellacicco \& Pavone, 2020); in consequence, it is concluded that although in some specific situations opportunities have been offered, it is evident that the participation of functionally diverse people in this setting is limited and unequal. In this regard, there is a direct relationship between the rights and the potentiation of capabilities in this segment of the population, as it allows us to examine the compatibility of a life in agreement with human dignity (Nussbaum, 2007, 2012). To Sen, it is essential to identify what is considered valuable (equality, social justice) in the plane of the satisfaction of preferences that lead to well-being, understood as the capacity that reflects the freedom to participate, to decide and to choose (Sen, 1999, 2008).

From the educational policy approach within the framework of inclusive education and work insertion, findings show that the UIS has inclusive processes in its guidelines and practices; however, there is a need to multiply the capabilities of the students and alumni, so that they undertake the junctures they encounter in life with autonomy and freedom, choices related with "being" and "doing". In consequence, it is expected that the UIS takes up its responsibility vehemently, strengthening internally its Inclusive Education Policy, with the projection of a Labour Insertion Policy for its alumni with diverse capabilities, eliminating all perception on disability from the medical and social models, as these are conceptions that lead to discriminatory and stigmatizing practices; adopting from its interest groups a bio-psychosocial model. In this sense, the actors involved from the framework of an Institutional Policy should 
understand that Human Development conceives the life of man and women under dignified conditions that make it possible to get access to opportunities in educational and labour contexts of respect, protection and the effective fulfillment of Human Rights (Zárate et al., 2017).

\section{References}

Aguilar, N., Moriña, A., \& Perera, V.H. (2019). Acciones del profesorado para una práctica inclusiva en la universidad. Revista Brasileira de Educação, 24, 1-19.

Akbieva Z., Damadaeva A., Magomedhanova U., \& Tajudinova G. (2015). Creation of the Center for Inclusive Education as an innovative project of college development in the field of inclusive education. Biosciences Biotechnology Reserch Asia, 12(3), 26732680. http://dx.doi.org/10.13005/bbra/1948

Álvarez-Pérez, R., \& López-Aguilar, D. (2015). Atención del profesorado universitario a estudiantes con necesidades educativas específicas. Educación y educadores, 18(2), 193-208. http://dx.doi.org/10.5294/edu.2015.18.2.1

Aoki, M., Silva, R.M., Souto, A.C.F., \& Oliver, F.C. (2018). People with disabilities and the development of community strategies to promote participation in the labor market. Revista Brasileira de Educação Especial, 24(4), 511-528. https://doi.org/10.1590/ S1413-65382418000500004

Artiles, A.J. (2019). Fourteenth Annual Brown Lecture in Education Research. Reenvisioning Equity Research: Disability Identification Disparities as a Case in point. Educational Researcher, 48(6), 325-335. https://doi.org/10.3102/0013189X19871949

Baeza, M.A. (2015). Hacer mundo. Significaciones imaginario-sociales para constituir sociedad. RIL.

Ballestín, B., \& Fàbregues, S. (2018). La práctica de la investigación cualitativa en ciencias sociales y de la educación. Universitat Oberta de Catalunya.

Bellacicco, R., \& Pavone, M. (2020). After higher education: exploring the transition

to employment for graduates with disabilities. ALTER, European Journal of Disability Research, 14, 159-174. https://doi.org/10.1016/j.alter.2020.03.002

Bliksvær, T. (2018). Disability, Labour Market Participation and the Effect of Educational Level: Compared to What? Scandinavian Journal of Disability Research, 20(1), 6-17. https://doi.org/10.16993/sjdr.3

Bonilla-Castro, E., \& Rodríguez, P. (2013). Más allá del dilema de los métodos: la investigación en Ciencias Sociales. Universidad de los Andes.

Brownell, M.T., Jones, N.D., Sohn, H., \& Stark, K. (2020). Improving Teaching Quality for Students With Disabilities: Establishing a Warrant for Teacher Education Practice. Teacher Education and Special Education, 43(1), 28-44. https://doi. org/10.1177/0888406419880351

Büscher-Touwen, M., de Groot, M., \& van Hal, L. (2018). Mind the Gap Between Higher Education and the Labour Market for Students with a Disability in the Netherlands: A Research Agenda. Social Inclusion, 6(4), 149-157. https://doi.org/10.17645/si.v6i4.1655

Cais, J., Folguera, L., \& Formoso, C. (2014). Investigación Cualitativa Longitudinal. Centro de Investigaciones Sociológicas. 
Canimas, J. (2015). ¿Discapacidad o diversidad funcional? Siglo Cero, 46(2), 79-97. http:// dx.doi.org/10.14201/scero20154627997

Cardona, J. (2013). Epistemología del saber docente. Universidad Nacional de Educación a Distancia.

Chavez, D., \& Yáñez-Canal, J. (2018). Fenomenología y psicología del desarrollo: la búsqueda de una articulación. Universidad Nacional de Colombia.

Colmenarejo, R. (2016). Enfoque de capacidades y sostenibilidad. Aportaciones de Amartya Sen y Martha Nussbaum. Ideas y Valores, 65(160), 121-149. http://dx.doi. org/10.15446/ideasyvalores.v65n160.43084

Cortés, M., \& Moriña-Díez, A. (2014). Luces y sombras en la Enseñanza Superior desde la perspectiva del alumnado con discapacidad en el área de Ciencias de la Salud. Revista de Investigación en Educación, 2(12), 164-175.

Darcy, S., Taylor, T., \& Green, J. (2016). 'But I can do the job': examining disability employment practice through human rights complaint cases. Disability $\mathcal{E}$ Society, 31(9), 1242-1274. https://doi.org/10.1080/09687599.2016.1256807

Denisova, O.A., Gudina, T.V., Lekhanova, O.L., Ponikarova, V.N., Bukina, I.A., \& Antonova, L.A. (2016). The Role of Regional Higher Education Institutions in Creating Conditions for People with Disabilities in Inclusive Educational Environment of the Russian Federation. Indian Journal of Science and Technology, 9(37), 1-9. https:// doi.org/10.17485/ijst/2016/v9i37/102171

De Tezanos, A. (1998). Una etnografía de la etnografía. Aproximaciones metodológicas para la enseñanza del enfoque cualitativo-interpretativo para la investigación social. Antropos.

del Pozo-Armentia, A., Reyero, D., \& Gil Cantero, F. (2020). The pedagogical limitations of inclusive education. Educational Philosophy and Theory, 52(10), 1064-1076. https:// doi.org/10.1080/00131857.2020.1723549

Girli, A., Sarı, H.Y., Kırkım, G., \& Narin, S. (2016). University students' attitudes towards disability and their views on discrimination. International Journal of Developmental Disabilities, 62(2), 98-107. https://doi.org/10.1179/2047387715Y.0000000008

González, E., \& Roses, S. (2016). ¿Barreras invisibles? Actitudes de los estudiantes universitarios ante sus compañeros con discapacidad. Revista Complutense de Educación, 27(1), 219-235. http://dx.doi.org/10.5209/rev_RCED.2016.v27.n1.45702

Gross, M. (2016). Accesibilidad al proceso educativo en el entorno universitario. Actualidades Investigativas en Educación, 16(1). 1-17. http://dx.doi.org/10.15517/aie.v16i1.21920

Hernández, C.E., \& Carpio, N. (2019). Introducción a los tipos de muestreo. ALERTA, 2(1), 75-79. https://doi.org/10.5377/alerta.v2i1.7535

Hernández-Sampieri, R., \& Mendoza, C. (2018). Metodología de la Investigación (6th ed.). McGraw-Hill.

Jiménez, J.C., \& Ruiz, E.F. (2018). Vulnerabilidad de las personas con discapacidad en México. Cinzontle, 10(22), 1-7.

Jurado, P., \& Soler, R. (2016). Workers with disabilities in sheltered employment centres: a training needs analysis. International Journal of Inclusive Education, 20(7), 756-769. https://doi.org/10.1080/13603116.2015.1111446

Kilinc, S. (2019). 'Who will fit in with whom?' Inclusive education struggles for students with dis/abilities. International Journal of Inclusive Education, 23(12), 1296-1314. https:// doi.org/10.1080/13603116.2018.1447612 
Kunnath, S.K., \& Mathew, S.N. (2019). Higher Education for Students with Disabilities in India: Insights from a Focus Group Study. Higher Education for the Future, 6(2), 171-187. https://doi.org/10.1177/2347631119840540

Kvale, S. (2011). Las entrevistas en Investigación Cualitativa. Morata.

Li, I.W., Mahuteau, S., Dockery, A.M., \& Junankar, P.N. (Raja). (2017). Equity in higher education and graduate labour market outcomes in Australia. Journal of Higher Education Policy and Management, 39(6), 625-641. https://doi.org/10.1080/136 0080X.2017.1377966

León, O.G., \& Montero, I. (2015). Métodos de investigación en psicología y educación. Las tradiciones cuantitativa y cualitativa (4th. ed.). McGraw-Hill Interamericana.

Lopez-Gavira, R., Moriña, A., \& Morgado, B. (2019). Challenges to inclusive education at the university: the perspective of students and disability support service staff. Innovation: The European Journal of Social Science Research. https://doi.org/10.1080/13 511610.2019 .1578198

Mañas, C., \& Iniesta, A. (2016). Barreras arquitectónicas, mentales y de comunicación: mujeres con diversidad funcional. La manzana de la discordia, 11(1), 55-71. http:// dx.doi.org/10.25100/lamanzanadeladiscordia.v11i1.1634

Maxwell, J. (2019). Diseño de investigación cualitativa. Gedisa.

Melero, N., Moriña, A., \& López-Aguilar, R. (2018). Life-Lines of Spanish Students with Disabilities during their University Trajectory. The Qualitative Report, 23(5), 1127-1145.

Moriña, A. (2019). The keys to learning for university students with disabilities: Motivation, emotion and faculty-student relationships. PLoS ONE, 14(5), 1-15. https:// doi.org/10.1371/journal.pone.0215249

Moriña, A., López, R., Melero, N., Cortés, M., \& Molina, V. (2013). El profesorado en la universidad ante el alumnado con discapacidad: ¿Tendiendo puentes o levantando muros? Redu, 11(3), 423-442. https://doi.org/10.4995/redu.2013.5537

Moriña, A., \& Morgado, B. (2018). University surroundings and infrastructures that are accessible and inclusive for all: listening to students with disabilities. Journal of Further and Higher Education, 42(1), 13-23. https://doi.org/10.1080/0309877X.2016.1188900

Moriña, A., \& Perera, V.H. (2020). Inclusive Higher Education in Spain: Students with Disabilities Speak Out. Journal of Hispanic Higher Education, 19(3), 215-231. https:// doi.org/10.1177/1538192718777360

Niño, V.M. (2019). Metodología de la investigación. Diseño, ejecución e informe (2nd. Ed.). Ediciones de la U.

Nussbaum, M. (2007). Las fronteras de la justicia. Consideraciones sobre la exclusión. Paidós.

Nussbaum, M. (2012). Crear capacidades. Propuesta para el desarrollo humano. Paidós.

Nussbaum, M. (2016). Introduction: Aspiration and the Capabilities List. Journal of Human Development and Capabilities, 17(3), 301-308. https://doi.org/10.1080/194528 29.2016.1200789

Ñaupas, H., Valdivia, M.R., Palacios, J.J., \& Romero, H.E. (2018). Metodología de la investigación cuantitativa-cualitativa y redacción de la tesis (5th ed.). Ediciones de la U.

Oviedo-Cáceres, M., \& Hernández-Quirama, A. (2020). Universidad y discapacidad: "La estrategia básica es la perseverancia". Revista Colombiana de Educación, 1(79), 395-422. https://doi.org/10.17227/rce.num79-9618 
Packer, M.J. (2018). La ciencia de la investigación cualitativa (2nd ed.). Universidad de los Andes.

Palacios, A. (2008). El modelo social de discapacidad: orígenes, caracterización y plasmación en la Convención Internacional sobre los Derechos de las Personas con Discapacidad. Cinca.

Pașcalău-Vrabete, A., \& Băban, A. (2018). Is 'different' still unacceptable? Exploring the experience of mobility disability within the Romanian social and built environment. Disability and Society, 33(10), 1601-1619. https://doi.org/10.1080/09687599.2018.1503592

Paz-Maldonado, E. (2020). Inclusión educativa del alumnado en situación de discapacidad en la educación superior: una revisión sistemática. Teoría de la Educación, 32(1), 123-146. http://dx.doi.org/10.14201/teri.20266

Peña, B. (2011). Métodos científicos de observación en educación. Visión Libros.

Pimienta, J.H., de la Orden, A., \& Estrada, R.M. (2018). Metodología de la investigación. Pearson.

Pugach, M.C., Blanton, L.P., Mickelson, A.M., \& Boveda, M. (2020). Curriculum Theory: The Missing Perspective in Teacher Education for Inclusion. Teacher Education and Special Education, 43(1), 85-103. https://doi.org/10.1177/0888406419883665

Polo, M.T., Chacón-López, H., Caurcel, M.J., \& Valenzuela, B. (2020). Attitudes towards Persons with Disabilities by Educational Science Students: Importance of Contact, Its Frequency and the Type of Disability. International Journal of Disability, Development and Education. https://doi.org/10.1080/1034912X.2020.1716960

Polo, M.T., Fernández-Jiménez, C., \& Fernández, M. (2018) The Attitudes of Different Partners Involved in Higher Education towards Students with Disabilities. International Journal of Disability, Development and Education, 65(4), 442-458. https://doi.org /10.1080/1034912X.2017.1406066

Rawls, J. (1995). Teoría de la justicia (2nd ed.). Fondo de Cultura Económica.

Robles, A., Robles, J., Giménez, F.J., \& Abad, M.T. (2016). Validación de una entrevista para estudiar el proceso formativo de judokas de élite. Revista Internacional de Medicina y Ciencias de la Actividad Física y el Deporte, 16(64), 723-738. http://dx.doi. org/10.15366/rimcafd2016.64.007

Rodríguez, S., \& Ferreira, M. (2010). Desde la dis-capacidad hacia la diversidad funcional. Un ejercicio de Dis-Normalización. Revista Internacional de Sociología, 68(2), 289-309. http://dx.doi.org/10.3989/ris.2008.05.22

Sandín, M. (2003). Investigación Cualitativa en Educación. Fundamentos y tradiciones. McGraw-Hill.

Sandoval, C. (2002). Investigación Cualitativa. ICFES.

Santórsola, M., Luján, F., Giuliano, M., Antón, C., \& Arroyo, J. (2013). Discapacidad e inclusión en el ámbito de la educación superior universitaria a partir del modelo social de la discapacidad. Didáctica y educación, 4(2), 1-16.

Sen, A. (1999). Nuevo examen de la desigualdad. Alianza.

Sen, A. (2000). Desarrollo y libertad. Planeta.

Sen, A. (2008). Capability and Well-Being. In: Hausman, D.M. (Ed.), The Philosophy of Economics (3rd ed., pp. 270-293). Cambridge.

Sen, A. (2012). Values and justice. Journal of Economic Methodology, 19(2), 101-108. http:// dx.doi.org/10.1080/1350178X.2012.683601 
Soares, E.B. (2019). Inclusion of professionals with disabilities in the workplace: challenges for the Human Resources Management. Gestão \& Produção, 26(3), e2871. https://doi.org/10.1590/0104-530X-2871-19

Toboso, M. (2018). Diversidad funcional: hacia un nuevo paradigma en los estudios y en las políticas sobre discapacidad. Política y Sociedad, 55(3), 783-804. http://dx.doi. org/10.5209/POSO.56717

Urquijo, M. (2008). La libertad como capacidad. En enfoque de las capacidades de Amartya Sen y sus implicaciones en la ética social y política. Universidad del Valle.

Vasilachis de Gialdino. (Coord.). (2019). Estrategias de investigación cualitativa. Volumen II. Gedisa.

Velázquez, H., Pietri, L., \& Maldonado, N. (2013). De la incapacidad a la diversidad funcional: Una mirada a la evolución histórica de los conceptos, significados e implicaciones para la intervención psicológica. Informes Psicológicos, 13(2), 79-101.

Villalobos, C., Rojas, C., \& Torrealba, D. (2015). Gestión de la heterogeneidad en las aulas chilenas. Técnicas, patrones de agrupamiento y sus efectos en el sistema educativo: un estudio de caso. Revista Latinoamericana de Educación Inclusiva, 9(1), 21-42.

Vorhaus, J. (2015). Dignity, capability, and profound disability. Metaphilosophy, 46(3), 462-478. http://dx.doi.org/10.1111/meta.12141

Vornholt, K., Villotti, P., Muschalla, B., Bauer, J., Colella, A., Zijlstra, F., Van Ruitenbeek, G., Uitdewilligen, S., \& Corbière, M. (2018). Disability and employment - overview and highlights. European Journal of Work and Organizational Psychology, 27(1), 40-55. https://doi.org/10.1080/1359432X.2017.1387536

Williams, T., \& Hagood, A. (2019). Disability, the Silent D in Diversity. Library Trends, 67(3), 487-496. https://doi.org/10.1353/lib.2019.0008

Williams, V., Tarleton, B., Heslop, P., Porter, S., Sass, B., Blue, S., Merchant, W., \& Mason-Angelow, V. (2018). Understanding disabling barriers: a fruitful partnership between Disability Studies and social practices? Disability \& Society, 33(2), 157-174. https://doi.org/10.1080/09687599.2017.1401527

World Health Organization [WHO]. (2001). International Classification of Functioning, Disability and Health. WHO.

Zárate, R., Mantilla, E., \& Rodríguez, D. (2017). Derechos Humanos. Una mirada retrospectiva. Ediciones Universidad Industrial de Santander.

Fecha de recepción: 13 de mayo de 2020.

Fecha de revisión: 22 de mayo de 2020.

Fecha de aceptación: 4 de septiembre de 2020. 